\title{
Öğretmenlerin Örgütsel Adalet Algılarının Örgütsel Sinizm Açısından İncelenmesi
}

\section{Sinan Yalçın ${ }^{1}$}

Type/Tür:

Research/Araştırma

Received/Geliş Tarihi: February

22/ 22 Şubat 2021

Accepted/Kabul Tarihi:

November 17/ 17 Kasim 2021

Page numbers/Sayfa No: 1581-

1604

Corresponding

Author/İletişimden Sorumlu

Yazar: sinan29@gmail.com

\section{$\checkmark$ iThenticate}

This paper was checked for plagiarism using iThenticate during the preview process and before publication. / Bu çalışma ön inceleme sürecinde ve yayımlanmadan önce iThenticate yazılımı ile taranmıştır.

Copyright $\odot 2017$ by

Cumhuriyet University, Faculty of Education. All rights reserved.

\section{Öz}

$\mathrm{Bu}$ araştırmada öğretmenlerin algılarına göre örgütsel adalet ile örgütsel sinizm arasındaki ilişki incelenmiştir. Araştırma nicel araştırma yönteminde ilişkisel tarama modelinde tasarlanmıştır. Araştırmanının evreninin 2020-2021 eğitim öğretim yılında Erzincan il merkezinde resmi okullarda görev yapmakta olan öğretmenler oluşturmaktadır. Araştırmanın örneklemini ise evrenden basit tesadüfi örnekleme yöntemi ile seçilen 240 öğretmen oluşturmaktadır. Araştırmanın verileri elektronik ortamda toplanmıştır. Araştırma verileri SPSS programı yardımı ile analiz edilmiştir. Araştırma sonuçlara göre öğretmenlerin örgütsel adalet algıları yüksek örgütsel sinizm algıları ise düşük çıkmıştır. Branş değişkenine göre ve görev yapılan okul türüne göre öğretmenlerin örgütsel adalet algıları anlamlı farklılık göstermektedir. Öğretmenlerin örgütsel sinizm algıları branş, kıdem ve görev yapılan okul türüne göre anlamlı farklılık gösterdiği sonucu elde edilmiştir. Araştırmadan elde edilen bir diğer sonuca göre öğretmenlerin örgütsel adalet algıları ile örgütsel sinizm algıları arasında negatif yönlü anlamlı bir ilişki olduğudur. Araştırmada öğretmenlerin örgütsel adalet algılarının örgütsel sinizm üzerinde anlamlı bir yordayıcı olduğu sonucuna ulaşılmıştır.

Anahtar Kelimeler: örgütsel adalet, örgütsel sinizm, öğretmen, eğitim, öğretim.

\section{Suggested APA Citation/Önerilen APA Atıf Biçimi:}

Yalçın, S. (2021). Öğretmenlerin örgütsel adalet algılarının örgütsel sinizm açısından incelenmesi.

Cumhuriyet International Journal of Education, 10(4), 1581-1604.

http://dx.doi.org/10.30703/cije.884936

\footnotetext{
${ }^{1}$ Doç.Dr, Erzincan Binali Yıldırım Üniversitesi, Eğitim Fakültesi, Associate Profesor, Erzincan Binali Yıldırım University, Faculty of Education e- mail: sinan29@gmail.com, ORCID ID: orcid.org/0000-0002-2372-9035
} 


\title{
Investigating the Organisational Justice Perceptions of Teachers in Terms of the Organisational Cynicism
}

\begin{abstract}
In this research, the relationship between the organisational justice and organisational cynicism according to teacher perceptions was investigated. The research was designed in the relational screening model and with the quantitative research method. The universe of the research consisted of the teachers working at the state schools in Erzincan city centre in the 2020-2021 educational year. The sample of the research was 20 teachers selected with the simple random sampling technique. The data of the research were collected electronically. These data were analysed with the SPSS program. According to the research results, the organisational justice perceptions of teachers were found to be high, however, their organisational cynicism perceptions were low. The organisational justice perceptions of teachers demonstrated significant difference according to the variables of branch and working school. The teachers' organisational cynicism perceptions demonstrated significant difference according to the variables of branch, year of experience and working school. According to another result from the research, it was found that there was a negative significant relationship between the organisational justice perceptions of teachers and their organisational cynicism perceptions. That the organisational justice perceptions of teachers was a significant predictor on their organisational cynicisms was another result of the research.
\end{abstract}

Keywords: Organisational justice, organisational cynicism, teacher, education, teaching

\section{Giriş}

Örgütler insan ihtiyaçlarından doğar. Örgütlerin amaçlarının gerçekleştirebilmeleri varlıklarını devam ettirebilmeleri açısından önemlidir. Örgütsel amaçların gerçekleşebilmesi çalışanların örgütsel amaçlar doğrultusunda bir çaba göstermelerine bağlıdır. Çalışanlar örgütsel amaçların gerçekleşmesi için bir çaba ortaya koyarak hem örgütün amaçlarının hem de kendi ihtiyaçlarının gerçekleşmesini sağlarlar. Bu anlamda örgüt ile çalışan arasında karşılıklı ihtiyaçların ve beklentilerin karşılanmasına yönelik bir ilişki ağ 1 söz konusudur.

Örgütlerde etkililiği ve verimliliği temel alan yönetim yaklaşımları örgütsel verimliliğ̆i ve etkililiğ̆i artırmanın yolu olarak çeşitli çc̈zümler ileri sürmüşlerdir. Bu yönetim yaklaşımlarından biri olan insan ilişkileri yaklaşımı örgütsel verimliliği ve etkililiğin arttırılması hususunda çalışanları ön plana alarak çalışanların insani özelliklerinin dikkate alınması gerektiğini ifade etmiştir. İnsan ilişkileri yaklaşımı ile birlikte örgütlerde çalışanlar önemli görülmeye başlanmış, çalışanların örgütsel amaçların gerçekleşmesi yönünde davranış sergilemelerinin yolları aranmaya başlanmiştır.

Bugünün örgüt yaşaminda karmaşıklık ve rekabet unsuru örgütleri rekabet edebilmek ve kar elde edebilmek için gelişmeye zorlamaktadır (Grama veToderıcıu, 2016). Küreselleşme ve rekabetin artması ile birlikte örgütsel başarının elde edilmesinin temel unsurunun insan kaynağı olduğu gerçeği örgütleri insan kaynağına olan ilgisini arttırmaya zorlamaktadır (Hazzi, 2012).

\section{Örgütsel Adalet}

Örgütsel adalet, insanların örgütlerdeki adalet algıları, son y1llarda endüstriyelörgütsel psikoloji, insan kaynakları yönetimi ve örgütsel davranış alanlarında bilim 
adamlarının en çok ilgilendiği konulardan biridir (Hazzi, 2012). Örgütsel adalet, insanların ortak amaçlar etrafında birlikte etkili bir şekilde çalışmasına izin veren unsurlardan biridir. Örgütsel Adalet, çalışanların örgüt ile olan ilişkisini ifade eder. Aksine, adaletsizlik, topluluk içindeki bağları çözebilecek aşındırıı bir çözücü gibidir. Adaletsizlik bireylere zarar verir ve kuruluşlara zarar verir (Cropanzano, Bowen ve Gilliland, 2007). Örgütsel adalet çalışanların örgütleri tarafından kendilerine adil davranılıp davranılmadığına ilişkin algıları ile ilgili bir kavramdır (Greenberg, 1987, Akt; Blakely, Andrews ve Moorman, 2005).

Greenberg (1997)'e göre örgütsel adalet çalışanların adalet kavramına ilişkin kurallar ile bu kuralların sonuçlarına ilişkin algıları ile şekillenen örgütsel yaşamdaki rollerinin ve görevlerinin açık ve örtük özelliklerine dayanan algısı şeklinde tanımlar (Kahveci, Karagül Kandemir ve Bayram, 2019). Greenberg (1990)'e göre çalışanlar örgüt içerisinde çabalarının karşıllı̆ını alma ve örgüt içerisinde karşılaştıkları muameleler neticesinde adalet kavramı ile ilgilenirler (Williams, Pıtre ve Zaınuba, 2002).

Türk Dil kurumu ise adalet kavramin "Yasalarla sahip olunan haklarm herkes tarafindan kullanilmasinin sağlanması, Hak ve hukuka uygunluk, hakkı gözetme, Herkese kendine uygun düşeni, kendi hakkı olanı verme, doğruluk" şeklinde tanımlamıştır (TDK). Moorman (1991) ise örgütsel adaleti, çalışanların örgütlerindeki iş ve işlemlerde kendilerine adaletli davranılıp davranılmadığını belirlemede kullandıkları yollar ve adalete ilişkin algılamalarının iş ile ilgili diğer konuları nasıl etkilediği ile ilgili bir kavram olarak tanımlamıştır (Uzun, 2018). Çalışanların beklentilerinin karşılanması ve örgütün amaçlarını gerçekleştirebilmesi için bir gereklilik olan örgütsel adalet, doğruluğun işyerindeki rolü ya da haklılığın korunmasında otoritenin işlevi olarak tanımlanmaktadır (Özer ve Günlük, 2010:460).

Yukarıda yapılan tanımlardan hareketle örgütsel adaleti, çalışanların örgütsel amaçlar doğrultusunda sergiledikleri performanslarının karşılı̆̆ına ilişkin algıları şeklinde tanımlamak mümkündür. Çalışanların örgütleri ile ilgili olumlu tutum sergilemeleri örgüte karşı olumlu düşüncelere sahip olmaları ile ilgilidir. Çalışanların örgütlerine ilişkin olarak olumlu davranış sergilemelerine neden olan birçok kavramdan bahsedilebilir. Bu kavramlardan biri de örgütsel adalet kavramidır. Çalışanların örgütsel adalet algıları ne kadar yüksek olursa örgütlerine karşı o denli olumlu davranış sergileyecekleri söylenebilir.

Örgütsel adalet, öğretmenlerin okulun amaçları doğrultusunda ortaya koyacağı performansını ve verimini etkilemesi bakımından okul örgütlerinde ayrı bir öneme sahiptir (Çelik ve Gürsel, 2017). Eğitim örgütlerinin en önemli ve açı özelliği, girdi ve çıktısının insanlardan oluşmasıdır. Böylece, okulun birey boyutu kurum boyutundan daha duyarlı, informal yanı formal yanından daha ağır etki alanı yetki alanından daha geniştir (Bursalığlu, 2002).

Okullar toplumun eğitim ihtiyacını karşılamak için faaliyet gösteren kurumlardır. Okullar hem girdi hem çıktı hem de süreç itibari ile insan kavramının başat olduğu kurumlardır. Bu özelliği ile okullar diğer örgüt yapılarından tamamen farklılaşırlar. Öğretmenlerin okullarına karşı algı ve tutumları olumlu olması okula yönelik davranışlarının da olumlu olması anlamını taşımaktadır. Bu anlamda adalet algısı yüksek olan öğretmenlerin okula yönelik olumlu tutum ve davranı̧̧ sergileyeceklerini söylemek yanlış olmaz. 
Okullar öğretmen, yönetici, öğrenci ve veli paydaşlarının sürekli etkileşim halinde oldukları karmaşık ve kapsamlı ilişkilerin yaşandığı yerlerdir. Bu etkileşimin yönünü belirleyen en önemli hususlardan biri okul yöneticisinin liderliği ve okulu yönetirken sergilediği yönetim anlayışıdır. Okul yöneticisinin bu davranış ve anlayış biçimi öğretmenler üzerindeki etkisi ve/ya algılanma biçimi öğretmenler için yönlendirici olmaktadır. Okul yöneticisinin adaletsiz uygulamaları ve 'kayırmacılık' davranışları pek çok açıdan öğretmenleri verimsizliğe doğru yönelten etmenler olabilmektedir. Bu tür uygulamalar öğretmenler nezdinde sinik tutumlara, düşük adalet algısına, muhalefet davranışlarına ve mutsuzluğa yol açabilmektedir (Korkut, Çelik ve Atik, 2015).

Öğretmenlerin okula katkılarından dolayı aldıkları ödüller dengeyi yansıtmalıdır; öğretmenler, katkılarının değerinin düşük olduğunu veya ödüllendirilmediğini düşünmemelidir. Genel olarak, öğretmenler ödüllerin çalışmaları, becerileri ve sorumluluklarıyla orantılı olarak dağıtılmasını beklerler. Adalet hem halka açık bir olay hem de bireysel bir yargıdır. Öğretmenlerin adalet algısı tatmin için bir anahtardır (Hoy ve Tarter, 2004).

Alanyazında okullarda örgütsel adalet kavramına yönelik olarak yapılan çalışmalar incelendiğinde; nepotizm ( Kaba, 2018), motivasyon (Çiçek, Sağlam ve Emir, 2018), örgütsel güven ve yıldırma ( Demirdağ, 2017), bağlılık ( Şahin ve Kavas, 2016), işe yabancılaşma ( Aydın, 2015), iş tatmini (Batman, 2015), örgütsel sessizlik ( İşleyici, 2015), örgütsel sinizm ( Çetin, Özgan ve Bozbayındır, 2015), Etik liderlik ( Kaya, 2014), Örgütsel vatandaşlik (Güneş ve Küçüksüleymanoğlu, 2020), İşle bütünleşme ( Akdeniz ve Ottekin-Demirbolat, 2019), Yönetici desteği ve Örgütsel özdeşleşme ( Uzun, 2018), örgütsel iki yüzlülük ( Kahveci, Karagül-Kandemir ve Bayram, 2019), Örgüt kültürü ve İş tatmini (Yücekaya ve Dönmez-Polat, 2020) kavramları ile örgütsel adalet kavramı arasındaki ilişki incelenmiştir. Yapılan araştırmalar örgütsel adalet algısının çalışanların örgüt içerisinde örgüte yönelik birçok davranışı etkilediği sonucunu ortaya koymaktadır. Örgütsel adalet algısının etkide bulunduğu kavramlardan biriside örgütsel sinizm davranışıdır.

\section{Örgütsel Sinizm}

Sinizm, ilgisizlik, istifa, yabancılaşma, umutsuzluk, başkalarına güven eksikliği, şüphe, hayal kırıklığı veya düşük performans, kişilerarası çatışmalar, devamsızlık, bitkinlik gibi bir dizi olumsuz unsurla ilişkilendirilmektedir (Andersson, 1996: akt: Grama ve Toderıcıu, 2016, s.49). Wilkerson'a (2002) göre örgütsel sinizm, "çalışanın örgütüne ve onun prosedürlerine, süreçlerine ve yönetimine karşı olumsuz bir tavırdır ve bu unsurların genellikle çalışanın çıkarlarına aykırı olduğuna dair bir inanca dayanır (Wilkerson, Evans ve Davis, 2008).

Andersson (1996)' na göre örgütsel sinizm, bir kişiye veya gruba yönelik hor görme ve güvensizlikle karakterize edilen hem genel hem de özel bir tutum olarak tanımlanabilir. Örgütsel sinizm, kişinin istihdam ettiği kuruluş hakkında sahip olduğu bir tutumdur. Tutum olarak, bir nesneye yönelik inançlar, duygulanımlar ve davranışsal eğilimlerden oluşur (Ajzen, 1994, Breckler, 1984; akt; Davis ve Gardner, 2004, s. 442). Örgütsel sinizm, çalışanların örgütlerinin dürüstlükten yoksun olduğuna inandıklarında ortaya çıkar (Dean, Brandes ve Dharwadkar, 1998). Örgütsel sinizmin anahtarı, örgütün bütünlükten yoksun olduğu inancıdır (Naus, Iterson ve Roe, 2007). 
Örgütsel sinizmi ortaya çıaran unsurlara yönelik olarak yapılan araştırmalar, örgütsel faktörlerin ve zayıf örgütsel performans ve işten çıkarmalar gibi olumsuz olayların daha yüksek düzeyde sinizme katkıda bulunduğunu göstermektedir (Anderson ve Bateman, 1997).

Dean vd (1998) örgütsel sinizmi, bilişsel boyut, duyuşsal boyut ve davranışsal boyut olarak üç boyutta değerlendirmişlerdir.

Bilişsel sinizm; Bilişsel boyutu örgüte ilişkin bütünlükten yoksun olduğuna dair inançlar oluşturur (Dean vd, 1998). Örgütsel sinizmin bu boyutunda çalışanlar örgütlerinin, dürüstlük, adalet ve güvenden yoksun olduklarına; bu kavramların çıkarlar doğrultusunda dikkate alınmayabileceğine inanmaktadırlar. Bu düşüncede olan çalışanlara göre, diğer çalışanların güvenilmez ve tutarsız kişiler olduğu, kararları kişisel çıarları doğrultusunda almaları gerektiği anlayışı hakimdir (Kutanis ve Dikili, 2010; Demirtaş, Özdemir ve Küu̧ük, 2016).

Duyuşsal sinizm; Duyuşsal boyutu örgüte ilişkin çalışanların olumsuz duyguları oluşturmaktadır (Dean vd, 1998). Birey bu duyguları kızgınlı- öfke, tiksinme-nefret gibi bir takım olumsuz duygulara dönüştürmektedir (Dean vd, 1998; Abraham, 2000; Demirtaş, Özdemir ve Küçük, 2016). Sinizm bireylerin olumsuz duygularıyla ilişkilidir. Sinik duyguya sahip bireyler, örgütlerine karşı öfke içinde olabilirler ya da örgütlerini düşündüklerinde bir takım olumsuz duygular içinde olabilirler (Dean vd., 1998).

Davranışsal sinizm; Davranışsal boyut ise örgüte yönelik olarak aşağılayıcı ve eleştirel davranışlarda bulunma şeklinde ifade edilebilir (Dean vd., 1998). Bu davranış eğilimleri, söz ya da hareketlerde gözlenebilmektedir (İnceoğlu, 2010). Bu boyutta çalışanların, örgüt yöneticilerine ve işlerine yönelik olarak olumsuz bir tavır içerisinde olmaları onları daha olumsuz davranışlar göstermeye yönelteceği beklenmektedir (Demirtaş, Özdemir ve Küçük, 2016).

Örgütsel sinizm çalışanların örgütlerine ve diğer çalışanlara yönelik olarak sahip olduğu olumsuz duygu, düşünce ve davranışları ifade ettiği için örgütler ve çalışanlar için yaşanması istenmeyen bir durumdur. Özünde olumsuzlukları içerdiği için örgütsel sinizm davranışı hem örgüte hem de çalışana zarar veren bir durumdur. Sinik davranışlar sergileyen bireylerin bu durumu örgütlerine ve işlerine yansıtacağ için örgütler açısından olumsuz durumları ortaya çıkarabilir. Çalışanların sinik davranışlar sergilemesi onların iş performansını olumsuz etkileyecek, örgütsel amaçların gerçekleşmesine zarar verecektir.

Eğitim örgütleri, girdisi ve çıktı insan olan dinamik bir yapıya sahiptir. Her örgütte olduğu gibi eğitim örgütlerinde de öğretmenlerin tutum ve davranışlarını etkileyen birçok etmenden söz edilebilir (Kalağan ve Güzeller, 2010). Eğitim örgütleri bağlamında değerlendirildiğinde örgütsel sinizm, öğretmenlerin okula ilişkin olumsuz tutumu olarak ifade edilebilir. Okul yöneticilerin öğretmenlerin sinizminin sebep ve sonuçlarını bilmeleri yöneticilere örgütteki başarı ve var ise sinizmin olumsuz sonuçlarını bertaraf etmede fırsatlar vermektedir. Örgütsel sinizmi etkileyen faktörlerin bilinmesi ya da algılanması olumsuz sonuçları doğurabilecek davranışların sergilenmesinin önüne geçecektir (Helvacı ve Çetin, 2012).

Örgütsel adaletin olmadığı ve böylelikle hak etmeyen bir kişinin ya da davranışın itibar göreceği düşüncesinin hâkim olduğu durumlarda öğretmenlerde örgütsel sinizm davranışı ortaya çıkabilir. Bu bağlamda, öğretmenlerde okula yönelik 
olumsuz tutum ve gelişebilir. Bu tutum, öğretmenin kişilik özelliklerinden, çalışma koşullarından ve okul yöneticilerinin öğretmenlere yönelik davranışlarından kaynaklanabilir (Altınkurt, Yılmaz, Erol ve Salalı, 2014). Öğretmenleri örgütsel sinizm davranışlarına neden olan durumların belirlenmesi ve öğretmenlerin örgüte dönük davranışlarını daha olumlu hale getirilmesi örgütsel etkililik ve verimlilik açısından yararlı olabilir (Demirtaş, Özdemir ve Küçük, 2016). Bu araştırmada da öğretmenlerin örgütsel adalet algılamalarının örgütsel sinizm davranışlarına ne tür bir etkide bulunduğu araştırılmıştır.

\section{Problem Cümlesi}

$\mathrm{Bu}$ araştırmanın problem cümlesini “ Öğretmenlerin algılarına göre örgütsel adalet ve örgütsel sinizm arasındaki ilişki" sorusu oluşturmaktadır. Bu amaçla aşağıdaki sorulara yanıt aranmıştır:

1. Öğretmenlerin örgütsel adalet ve örgütsel sinizm algıları ne düzeydedir?

2. Öğretmenlerin örgütsel adalet ve örgütsel sinizm algıları demografik değişkenlere göre farklılaşmakta mıdır?

3. Öğretmenlerin örgütsel adalet, örgütsel sinizm arasında anlamlı bir ilişki var midir?

4. Öğretmenlerin örgütsel adalet algıları, örgütsel sinizm algılarının anlamlı bir yordayıcısı midir?

\section{Araştırma Modeli}

\section{Yöntem}

$\mathrm{Bu}$ araştırma, nicel araştırma yöntemlerinden ilişkisel tarama modelinde tasarlanmıştır. İlişkisel tarama modelinde iki ve daha çok sayıdaki değişken arasında birlikte değişimin varlığı ve/ veya derecesi belirlenmeye çalışılır (Karasar, 2007).

\section{Evren ve Örneklem}

Araştırmanın çalışma grubunu 2018-2019 eğitim öğretim yılında Erzincan il merkezinde görev yapan öğretmenler arasından rastgele örnekleme yöntemi ile seçilen 240 öğretmen oluşturmaktadır. Erzincan il merkezinde 48 ilkokul (597 öğretmen), 38 ortaokul (855 öğretmen), 33 ortaöğretim (991 öğretmen) yer almaktadır. Örneklem gurubunda yer alan öğretmenlerin demografik bilgileri Tablo 1 de sunulmuştur. 
Tablo 1

Araştırmaya Katılan Öğretmenlerin Demografik Bilgileri

\begin{tabular}{|c|c|c|c|c|c|c|c|}
\hline Seçenekler & & 1 & 2 & 3 & 4 & 5 & Toplam \\
\hline \multirow{3}{*}{ Cinsiyet } & & Erkek & Kadin & & & & - \\
\hline & $\eta$ & 149 & 91 & & & & 240 \\
\hline & $\%$ & 62.1 & 37.9 & & & & 100 \\
\hline \multirow{3}{*}{ Branş } & & Sinif & Branş & & & & - \\
\hline & $\eta$ & 90 & 150 & & & & 240 \\
\hline & $\%$ & 37.5 & 62.5 & & & & 100 \\
\hline \multirow{3}{*}{ Kidem } & & $1-5$ & $6-10$ & $11-15$ & $16-20$ & $21-$ & \\
\hline & $\eta$ & 57 & 61 & 47 & 42 & 33 & 240 \\
\hline & $\%$ & 23.8 & 25.4 & 19.6 & 17.5 & 13.8 & 100 \\
\hline \multirow{3}{*}{ Okul Türü } & & İlkokul & Ortaokul & Lise & & & \\
\hline & $\eta$ & 95 & 95 & 50 & & & 240 \\
\hline & $\%$ & 39.6 & 39.6 & 20.8 & & & 100 \\
\hline \multirow{3}{*}{ Medeni Durum } & & Evli & Bekâr & & & & \\
\hline & $\eta$ & 187 & 53 & & & & 240 \\
\hline & $\%$ & 77.9 & 22.1 & & & & 100 \\
\hline
\end{tabular}

\section{Veri Toplama Araçları}

Araştırmanın verilerini toplamak amacı ile örgütsel adalet ölçeği, örgütsel muhalefet ölçeği ve örgütsel sinizm ölçeği kullanılmıştır

Örgütsel adalet ölçeği. Örgütsel adalet ölçeği Hoy ve Tarter (2004) tarafından geliştirimiş ve Taşdan ve Yılmaz (2010) tarafından Türkçe uyarlaması yapılmıştır. Ölçek tek boyutlu, 5'li likert tipinde hazırlanmış 10 adet görüşme sorusundan oluşmaktadır. Ölçekte ters madde bulunmamaktadır. Araştırmacılar tarafından ölçeğin güvenirlik katsayısı a $=.92$ olarak belirlenmiştir. $\mathrm{Bu}$ araştırma kapsamında yapılan güvenirlik analizleri sonucunda ölçeğin Cronbach Alpha güvenirlik katsayısı $a=.94$ olarak hesaplanmıştır. Bu sonuca göre ölçeğin yüksek düzeyde güvenirliğe sahip olduğu görülmüştür.

Örgütsel sinizm ölçeği. Örgütsel sinizm ölçeği Brandes vd. (1999) tarafından geliştirilmiş ve Kalağan (2009) tarafından Türkçe'ye uyarlanmıştır. Ölçek üç alt boyuttan ve 13 maddeden oluşmaktadır. Kalağan (2009) tarafından yapılan güvenirlik analizinde "bilişsel sinizm" alt boyutuna ait güvenirlik katsayısı .91, duyuşsal sinizm" alt boyutunda .95 "davranışsal sinizm" alt boyutunda ise .87 olarak hesaplanmıştır. Bu araştırma için yapılan güvenirlik analizleri sonucunda örgütsel sinizmin "bilişsel" alt boyutuna ait Cronbach alfa güvenirlik katsayısı .89, duyuşsal" alt boyutunda 98 "davranışsal" alt boyutunda ise .78 olarak hesaplanmıştır. Ölçeğin geneline ait Cronbach alfa güvenirlik katsayısı ise .93 olarak bulunmuştur. Bu sonuçlara göre ölçeğin yüksek güvenirliğe sahip olduğu söylenebilir.

\section{Verilerin Analizi}

Araştırmadan elde edilen veriler normallik testine tabi tutulmuş verilerin normal dağılım gösterdiği gözlenmiştir. Verilere ait çarpıklık ve basıklık değerlerininde +1 ile -1 aralığında değiştiği görülmüştür. Normallik testine ilişkin bilgiler tablo. 2' de sunulmuştur. 
Tablo.2

Araştırma Değişkenlerine İlişkin Normallik Testi Sonuçları

\begin{tabular}{lll}
\hline & Çarpıklık (Skewness) & Basıklı (Kurtosis) \\
\hline Bilişsel sinizm &, 211 &,- 622 \\
\hline Duyuşsal sinizm &, 804 &, 089 \\
\hline Davranışsal sinizm &, 180 &,- 656 \\
\hline Örgütsel sinizm &, 298 &,- 745 \\
\hline Örgütsel adalet &,- 510 &,- 579 \\
\hline
\end{tabular}

Yapılan normallik testleri sonucunda verilerin normal dağılım gösterdiği görülmüş, elde edilen bu sonuçlardan sonra verilerin analizine geçilmiştir. Verilerin analizinde bağımsız t testi, tek yönlü ANOVA, korelasyon analizi ve regresyon analizi yöntemleri kullanılmıştır.

\section{Araştırmanın Etik İzinleri}

Yapılan bu çalışmada "Yükseköğretim Kurumları Bilimsel Araştırma ve Yayın Etiği Yönergesi" kapsamında uyulması belirtilen tüm kurallara uyulmuştur. Yönergenin ikinci bölümü olan “Bilimsel Araştırma ve Yayın Etiğine Aykırı Eylemler" başlı̆̆ı altında belirtilen eylemlerden hiçbiri gerçekleştirilmemiştir.

Etik kurul izin bilgileri

Etik değerlendirmeyi yapan kurul adı $=$ Erzincan Binali Yıldırım Üniversitesi İnsan Araştırmaları Etik Kurulu

Etik değerlendirme kararının tarihi= 18/12/2020

Etik değerlendirme belgesi sayı numarası=11/15

\section{Bulgular ve Yorum}

Öğretmenlerin örgütsel adalet ve örgütsel sinizm algılarının ne düzeyde olduğuna ilişkin yapılan analizler sonucunda elde edilen bulgular alt problemler halinde Tablo $3^{\prime}$ te sunulmuştur.

\section{Birinci Alt Probleme İlişkin Bulgular}

Tablo $3^{\prime}$ te öğretmenlerin örgütsel adalet algılarının yüksek düzeyde olduğu, bilişsel sinizm, duyuşsal sinizm, davranışsal sinizm ve örgütsel sinizm algılarının düşük düzeyde olduğu görülmektedir.

Tablo 3

Öğretmenlerin Örgütsel Adalet, Örgütsel Sinizm Algı Düzeyleri

\begin{tabular}{llll}
\hline & $\mathrm{N}$ & $\bar{X}$ & Ss \\
Örgütsel adalet & 240 & 3,67 & 0,90 \\
Bilişsel sinizm & 240 & 2,35 & 0,86 \\
Duyuşsal sinizm & 240 & 1,84 & 0,85 \\
Davranişsal sinizm & 240 & 2,50 & 0,80 \\
Örgütsel sinizm & 240 & 2,24 & 0,72 \\
\hline
\end{tabular}




\section{İkinci Alt Probleme İlişkin Bulgular}

Tablo 4 incelendiğinde öğretmenlerin örgütsel adalet ve örgütsel sinizm algıları cinsiyet ve medeni durum değişkenine göre anlamlı bir farklılık göstermezken alan bilgisi değişkenine göre öğretmenlerin örgütsel adalet, bilişsel sinizm, duyuşsal sinizm, davranışsal sinizm ve örgütsel sinizm algılarının anlamlı bir farklılık gösterdiği görülmektedir. Aritmetik ortalamalar dikkate alındığında sınıf öğretmenlerinin örgütsel adalet algıları branş öğretmenlerine göre daha yüksek düzeydedir. Öğretmenlerin örgütsel sinizm algılarına ortalamalar nezdinde bakıldığında branş öğretmenlerinin bilişsel sinizm, duyuşsal sinizm, davranışsal sinizm ve örgütsel sinizm algılarının sınıf öğretmenlerine göre daha yüksek olduğu görülmektedir.

Tablo 4

Öğretmenlerin Örgütsel Adalet Ve Örgütsel Sinizm Algılarnnı Cinsiyet, Medeni Durum Ve Alan Bilgisi Değiş̧kenlerine Göre Farklılaşıp Farklılaşmadığına İlişkin T Testi Analizi Sonuçlan

\begin{tabular}{|c|c|c|c|c|c|c|c|}
\hline & $\mathrm{N}$ & $\bar{x}$ & Ss & Erkek & Bayan & $\mathrm{P}$ & $\mathrm{t}$ \\
\hline \multirow[t]{2}{*}{ Örgütsel adalet } & 149 & 3,64 & 0,90 & 3,64 & 3,71 &, 580 &,- 554 \\
\hline & 91 & 3,71 & 0,92 & & & & \\
\hline \multirow[t]{2}{*}{ Bilişsel sinizm } & 149 & 2,42 & 0,88 & 2,42 & 2,23 & ,099 & 1,658 \\
\hline & 91 & 2,23 & 0,83 & & & & \\
\hline \multirow[t]{2}{*}{ Duyuşsal sinizm } & 149 & 1,84 & 0,87 & 1,84 & 1,85 & 999 & 001 \\
\hline & 91 & 1,85 & 0,84 & & & & \\
\hline \multirow[t]{2}{*}{ Davranışsal sinizm } & 149 & 2,55 & 0,76 & 2,56 & 2,41 & 169 &,- 554 \\
\hline & 91 & 2,41 & 0,83 & & & & \\
\hline \multirow[t]{3}{*}{ Örgütsel sinizm } & 149 & 2,29 & 0,73 & 2,29 & 2,17 & 218 & 1,235 \\
\hline & 91 & 2,17 & 0,71 & & & & \\
\hline & $\mathrm{N}$ & $\bar{x}$ & Ss & Evli & Bekâr & $\mathrm{p}$ & $\mathrm{t}$ \\
\hline \multirow[t]{2}{*}{ Örgütsel adalet } & 187 & 3,72 & 0,92 & 3,72 & 3,46 & ,064 & 1,864 \\
\hline & 53 & 3,46 & 0,83 & & & & \\
\hline \multirow[t]{2}{*}{ Bilişsel sinizm } & 187 & 2,34 & 0,90 & 2,33 & 2,41 &, 582 &,- 552 \\
\hline & 53 & 2,41 & 0,71 & & & & \\
\hline \multirow[t]{2}{*}{ Duyuşsal sinizm } & 187 & 1,83 & 0,87 & 1,83 & 1,91 & ,556 &,- 589 \\
\hline & 53 & 1,91 & 0,81 & & & & \\
\hline \multirow[t]{2}{*}{ Davranışsal sinizm } & 187 & 2,45 & 0.82 & 2,44 & 2,68 & ,061 & $-1,883$ \\
\hline & 53 & 2,68 & 0,75 & & & & \\
\hline \multirow[t]{3}{*}{ Örgütsel sinizm } & 187 & 2,21 & 0,74 & 2,22 & 2,34 & ,267 & $-1,112$ \\
\hline & 53 & 2,34 & 0,63 & & & & \\
\hline & $\mathrm{N}$ & $\bar{x}$ & Ss & Sinif & Branş & $\mathrm{p}$ & $\mathrm{t}$ \\
\hline \multirow[t]{2}{*}{ Örgütsel adalet } & 90 & 3,95 & 0,84 & 3,95 & 3,50 &, $000^{*}$ & 3,809 \\
\hline & 150 & 3,50 & 0,90 & & & & \\
\hline \multirow[t]{2}{*}{ Bilişsel sinizm } & 90 & 2,13 & 0,92 & 2,13 & 2,49 &, $002^{*}$ & $-3,202$ \\
\hline & 150 & 2,49 & 0,80 & & & & \\
\hline \multirow[t]{2}{*}{ Duyuşsal sinizm } & 90 & 1,61 & 0,81 & 1,60 & 1,99 & , $001^{*}$ & $-3,438$ \\
\hline & 150 & 1,99 & 0,86 & & & & \\
\hline \multirow[t]{2}{*}{ Davranışsal sinizm } & 90 & 2,36 & 0,90 & 2,36 & 2,58 &, $041^{*}$ & $-2,057$ \\
\hline & 150 & 2,58 & 0,73 & & & & \\
\hline \multirow[t]{2}{*}{ Örgütsel sinizm } & 90 & 2,04 & 0,77 & 2,04 & 2,37 &, $001^{*}$ & $-3,451$ \\
\hline & 150 & 2,37 & 0,67 & & & & \\
\hline
\end{tabular}


Tablo 5

Öğretmenlerin Örgütsel Adalet Ve Örgütsel Sinizm Algılarının Kıdem ve Okul Türüne Göre Farklılaşıp Farklılaşmadığına İlişkin Tek Yönlü ANOVA Analizi Sonuçlan

\begin{tabular}{|c|c|c|c|c|c|c|c|}
\hline & $\begin{array}{l}1.1-5 \\
N=57\end{array}$ & $\begin{array}{l}2.6-10 \\
N=61\end{array}$ & $\begin{array}{l}3.11-15 \\
N=47\end{array}$ & $\begin{array}{l}4.16-20 \\
N=42\end{array}$ & $\begin{array}{l}5.21 \text { ve üzeri } \\
\mathrm{N}=33\end{array}$ & $\mathrm{~F}$ & $\mathrm{p}$ \\
\hline Örgütsel adalet & 3,62 & 3,55 & 3,52 & 3,99 & 3,75 & 1,998 & ,096 \\
\hline Bilişsel sinizm & 2,18 & 2,40 & 2,60 & 2,13 & 2,47 & 2,433 & $, 048 * 3>1,3>4$ \\
\hline Duyuşsal sinizm & 1,85 & 1,89 & 2,01 & 1,64 & 1,82 & 1,021 & ,397 \\
\hline Davranışsal sinizm & 2,62 & 2,65 & 2,54 & 2,20 & 2,34 & 2,706 & $\begin{array}{l}, 031^{*} 1>4 \\
2>4,3>4\end{array}$ \\
\hline \multirow[t]{2}{*}{ Örgütsel sinizm } & 2,21 & 2,32 & 2,40 & 2,01 & 2,23 & 1,923 & 107 \\
\hline & $\begin{array}{l}\text { 1.illkok } \\
\text { ul } \\
\mathrm{N}=95\end{array}$ & $\begin{array}{l}\begin{array}{l}\text { 2.Ortaok } \\
\text { ul } \\
\mathrm{N}=95\end{array}\end{array}$ & $\begin{array}{l}\text { 3.Lise } \\
N=50\end{array}$ & & & $\mathrm{~F}$ & $\mathrm{p}$ \\
\hline Örgütsel adalet & 3,87 & 3,53 & 3,54 & & & 3,992 &, $020 * 1>2$ \\
\hline Bilişsel sinizm & 2,16 & 2,50 & 2,43 & & & 3,951 &, $021 * 2>1$ \\
\hline Duyuşsal sinizm & 1,67 & 1,94 & 2,01 & & & 3,627 &, $028^{*} 2>1$ \\
\hline Davranışsal sinizm & 2,39 & 2,59 & 2,54 & & & 1,430 & 241 \\
\hline Örgütsel sinizm & 2,08 & 2,35 & 2,33 & & & 4,012 &, $019 * 2>1$ \\
\hline
\end{tabular}

Tablo 5 incelendiğinde öğretmenlerin kıdem değişkenine göre örgütsel adalet, duyuşsal sinizm ve genel örgütsel sinizm algıları arasında herhangi bir anlamlı farklılık ortaya çıkmazken, öğretmenlerin örgütsel sinizm algılarının bilişsel ve davranışsal sinizm boyutlarında kıdem değişkenine göre anlamlı farklılık gösterdiği görülmektedir. Bilişsel sinizm boyutunda ortaya çıkan bu farklılı̆̆ın kaynağına yönelik olarak yapılan PostHoc testlerinde ortaya çıkan farklılığın 11-15 yıllık mesleki kıdeme sahip öğretmenler ile 1-5 yıllık ve 16-20 yıllık mesleki kıdeme sahip öğretmenler arasında 11-15 yıllık mesleki kıdeme sahip öğretmenler lehine olduğu görülmektedir. Davranışsal sinizm boyutunda ortaya çıkan farklılığın kaynağına ilişkin olarak yapılan PostHoc testleri sonucunda ortaya çıkan farklılığın 1-5 yıllık kıdeme sahip öğretmenler ile 16-20 yıllık mesleki kıdeme sahip öğretmenler arasında 1-5 yıllık kıdeme sahip öğretmenler lehine, 6-10 yıllık kıdeme sahip öğretmenler ile 1620 yıllık kıdeme sahip öğretmenler arasında 6-10 yıllık kıdeme sahip öğretmenler lehine, 11-15 yıllık kıdeme sahip öğretmenler ile 16-20 yıllık kıdeme sahip öğretmenler arasında 11-15 yıllık kıdeme sahip öğretmenler lehine olduğu görülmüştür. Görev yapılan okul türü değişkeni dikkate alındığında yapılan tek yönlü Anova ve PostHoc 
testleri sonucunda öğretmenlerin örgütsel adalet algılarının ilkokul öğretmenleri ile ortaokul öğretmenleri arasında ilkokul öğretmenleri lehine anlamlı bir farklılığın ortaya çıktı̆̆1 görülmüştür. Örgütsel sinizm açısından incelendiğinde ise öğretmenlerin bilişsel sinizm, duyuşsal sinizm ve örgütsel sinizm algılarının ortaokul öğretmenleri ile ilkokul öğretmenleri arasında ortaokul öğretmenleri lehine anlamlı bir farklılık ortaya çıkmıştır. Öğretmenlerin davranışsal sinizm algıları arasında ise anlamlı bir farklılık ortaya çıkmamıştır.

\section{Üçüncü Alt Probleme İlişkin Bulgular}

Tablo 6 incelendiğinde örgütsel adalet ile örgütsel sinizm arasında $(r=-, 763)$ negatif yönlü yüksek düzeyde anlamlı bir ilişki olduğu söylenebilir. Örgütsel adalet ile örgütsel sinizm alt boyutları arasındaki ilişkiye bakıldığında, örgütsel adalet ile bilişsel sinizm arasında ( $r=-, 712)$ negatif yönde yüksek düzeyde anlamlı bir ilişki olduğu, örgütsel adalet ile duyuşsal sinizm arasında $(\mathrm{r}=-, 653)$ negatif yönlü orta düzeyde anlamlı bir ilişki olduğu, örgütsel adalet ile davranışsal sinizm arasında $(r=-, 574)$ negatif yönlü anlamlı bir ilişki olduğu ifade edilebilir. Bu sonuçlardan hareketle öğretmenlerin örgütsel adalet algıları arttıkça örgütsel sinizm davranışlarında bir azalma olacağı söylenebilir. Başka bir ifade ile okullarda adaletli uygulamalrın olması öğretmenlerin okullarına karşı olumsuz düşüncelere ve davranışlara sahip olma düzeylerini azalttığı ifade edilebilir.

Tablo 6

Öğretmenlerin Örgütsel Adalet Ve Örgütsel Sinizm Algıları Arasındaki İlişki

\begin{tabular}{lcccc} 
Örgütsel adalet & 1 & 2 & 3 & 4 \\
Bilişsel sinizm & 1 & & & \\
Duyuşsal sinizm &,$- 712^{* *}$ & 1 & & \\
Davranışsal sinizm &,$- 653^{* *}$ &, $603^{* *}$ & 1 & \\
Örgütsel sinizm &,$- 574^{* *}$ &, $554^{* *}$ &, $637^{* *}$ & 1 \\
\hline
\end{tabular}

\section{Dördüncü Alt Probleme İlişkin Bulgular}

Tablo 7 incelendiğinde öğretmenlerin örgütsel adalet algılarının bilişsel sinizm, duyuşsal sinizm, davranışsal sinizm ve genel örgütsel sinizm algılarının anlamlı bir yordayıcısı olduğu ve bilişsel sinizm yaklaşık olarak \%50'sinin, duyuşsal sinizmin \%43'ünün, davranışsal sinizmin \%33'ünün ve genel örgütsel sinizmin \%58'inin öğretmenlerin örgütsel adalet algılarından kaynaklandığı görülmektedir. 
Tablo 7

Öğretmenlerin Örgütsel Adalet Algılarının Örgütsel Sinizmi Yordamasına İlişkin Regresyon Analizi

\begin{tabular}{|c|c|c|c|c|c|}
\hline Bilişsel sinizm & B & $\mathrm{SH}_{\mathrm{B}}$ & $\beta$ & $\mathrm{t}$ & $\mathrm{p}$ \\
\hline Sabit & 24,205 & 820 & & 29,154 & ,000 \\
\hline Örgütsel adalet &,- 399 & ,022 &,- 712 & $-15,623$ &, 000 \\
\hline \multicolumn{6}{|l|}{$\mathrm{R}=, 712, \mathrm{R}^{2}=, 506$} \\
\hline \multicolumn{6}{|l|}{ Duyuşsal sinizm } \\
\hline Sabit & 16,456 & 701 & & 23,468 & 000 \\
\hline Örgütsel adalet &,- 247 & ,019 &,- 653 & $-13,309$ & 000 \\
\hline \multicolumn{6}{|l|}{$\mathrm{R}=, 653 \quad \mathrm{R}^{2}=, 427$} \\
\hline \multicolumn{6}{|l|}{ Davranışsal sinizm } \\
\hline Sabit & 17,470 & ,711 & & 24,557 &, 000 \\
\hline Örgütsel adalet &,- 203 & ,019 &,- 574 & $-10,811$ & 000 \\
\hline \multicolumn{6}{|l|}{$\mathrm{R}=, 574 \quad \mathrm{R}^{2}=, 329$} \\
\hline \multicolumn{6}{|l|}{ Örgütsel sinizm } \\
\hline Sabit & 58,131 & 1,639 & & 35,469 &, 000 \\
\hline Örgütsel adalet &,- 789 & ,043 &,- 763 & $-18,204$ & ,000 \\
\hline $\mathrm{R}=, 763 \quad \mathrm{R}^{2}=, 582$ & & & & & \\
\hline
\end{tabular}

\section{Tartışma, Sonuç ve Öneriler}

Öğretmenlerin örgütsel adalet algıları ile örgütsel sinizm algıları arasındaki ilişkinin incelendiği bu araştırmada elde edilen sonuçlar aşağıda sunulmuştur.

\section{Birinci Alt Probleme İlişkin Sonuçlar:}

Öğretmenlerin örgütsel adalet algıları yüksek çıkmıştır. Bu sonuçtan hareketle öğretmenlerin okullarında olumlu yönde adalet duygusuna sahip oldukları ve okul yönetim sürecinde okul yöneticilerini adil buldukları ifade edilebilir. Alanoğlu ve Demirtaş (2019), Babaoğlan ve Ertürk (2013), Demirdağ (2017), Kahveci, KaragülKandemir ve Bayram (2019), Kıranlı- Güngör ve Potuk (2018), Korkut (2019), Külekçi Akyavuz (2017), Kurtulmuş ve Karabıyık (2016), Özgit (2019), Şamdan ve Atanur Başkan (2019), Şahin ve Kavas (2016), Uluda ̆̆, Aktaş ve Özdoğaç-Özgit (2019), Uzun (2018), tarafından yapılan araştırmada öğretmenlerin örgütsel adalet algılarının yüksek çıktığı sonucuna ulaşılmıştır. Araştırma sonuçlarına göre öğretmenlerin örgütsel sinizm algıları düşük çıkmıştır. Gökyer ve Türkoğlu (2018), Güçlü, Kalkan ve Dağlı (2017), Helvacı ve Çetin (2012), Korkut (2019), Sezgin-Nartgün ve Kartal (2013), Şamdan (2019), Şamdan ve Atanur-Başkan (2019), Tazegül-Aydın (2017), Uludağ (2018), Uzun ve Ayık (2016), Yıldız (2013), Yıldırım, Akan ve Yalçın (2019), Yıldız (2013), yaptıkları araştırmada öğretmenlerin örgütsel sinizm algılarının düşük düzeyde olduğu sonucuna ulaşmışlardır. Balay, Kaya ve Cülha (2013), Demirtaş, Özdemir ve Küçük (2016), Ergen ve İnce (2017), Yorulmaz ve Çelik (2016) tarafından yapılan araştırmada öğretmenlerin örgütsel sinizm algıları orta düzeyde çıkmıştır. Bu araştırma kapsamında öğretmenlerin örgütsel sinizm düzeylerinin düşük çıkması, mesleki özellikleri bakımından öğretmenlik mesleğinin fedakârlık gerektiren, insani ilişkilerin yoğun olduğu, manevi duyguların daha ön planda olduğu bir meslek olmasından kaynaklanıyor olabilir. Okul girdisi ve çıktısı insan olan bir örgüt olarak 
değerlendirildiğinde okullarda insani ilişkilerin yoğun olması öğretmenlerde sinik davranışları engelleyen bir durum olarak ifade edilebilir.

\section{İkinci Alt Probleme İlişkin Sonuçlar}

Yapılan analizler sonucunda öğretmenlerin örgütsel adalet ve örgütsel sinizm algılarının cinsiyet ve medeni durum değişkenine göre anlamlı bir farklılık ortaya çıkmazken, alan bilgisi değişkenine göre öğretmenlerin örgütsel adalet ve genel örgütsel sinizm ve bütün alt boyutlarına ilişkin algıları arasında anlamlı bir farklılık ortaya çıkmıştır. Yapılan analizler neticesinde sınıf öğretmenlerinin örgütsel adalet algıları ortalamaları branş öğretmenlerine göre daha yüksek çıkarken, genel örgütsel sinizm algıları, bilişsel, duyuşsal ve davranışsal sinizm algıları ortalamaları branş öğretmenlerinde daha yüksek çıkmıştır. Polat ve Celep (2008) tarafından yapılan araştırmada öğretmenlerin örgütsel adalet algılarının erkek öğretmenler lehine anlamlı farklılık gösterdiği sonucuna ulaşılmıştır. Baş ve Şentürk (2011) tarafından yapılan araştırmada ise öğretmenlerin örgütsel adalet algılarının cinsiyet, mesleki kıdem değişkenlerine göre anlamlı bir farklılık göstermediği sonucuna ulaşılmıştır. Polat (2007) tarafından yapılan araştırmada öğretmenlerin cinsiyete göre örgütsel adalet algılarının farklılaşmadığı kıdem değişkenine göre ise anlamlı bir farklılık gösterdiği sonucuna ulaşılmıştır. Balay, Kaya ve Cülha (2013), Helvacı ve Çetin (2012) tarafından yapılan araştırma da öğretmenlerin örgütsel sinizm algılarının cinsiyete göre farklılaşmadığı sonucuna ulaşılmıştır. Bölükbaşıŏ̆lu (2013), Yılmaz (2010) tarafından yapılan çalışmada öğretmenlerin örgütsel adalet algılarının cinsiyet ve branş değişkenine göre farklılık göstermediği sonucuna ulaşılmıştır. Ünlü, Hamedoğlu ve Yaman (2015) tarafından yapılan çalışmada ise öğretmenlerin örgütsel adalet algılarının cinsiyete göre farklılaşmadığı fakat okul türüne göre anlamlı bir farklılık gösterdiği liselerde görev yapan öğretmenlerin örgütsel adalet algılarının ilkokul ve ortaokul öğretmenlerine göre daha düşük düzeyde olduğu sonucuna ulaşılmıştır. Alanoğlu ve Demirtaş (2019) ve Kalman ve Gedikoğlu (2014) tarafından yapılan bir başka araştırmada ise öğretmenlerin örgütsel adalet algılarının cinsiyet ve mesleki kıdem değişkenine göre göre anlamlı bir farklılık göstermediği sonucuna ulaşılmıştır. Şamdan (2019) tarafından yapılan araştırmada öğretmenlerin örgütsel adalet algıları cinsiyete anlamlı bir farklılık gösterdiği, erkek öğretmenlerin kadın öğretmenlere göre örgütsel adalet algılarının daha yüksek düzeyde olduğu sonucuna ulaşılmıştır.

Elde edilen bir diğer sonuca göre öğretmenlerin örgütsel adalet algılarının kıdem değişkenine göre herhangi bir farklılık göstermediği, görev yapılan okul türüne göre ise anlamlı bir farklılık gösterdiği sonucuna ulaşılmıştır. Bu sonuçlara göre ilkokul öğretmenleri ortaokul öğretmenlerine göre okullarındaki yönetim süreçlerini daha adil buldukları ifade edilebilir. Polat ve Celep (2008) tarafından yapılan araştırma da öğretmenlerin örgütsel adalet algılarının kıdem değişkenine göre anlamlı bir farklılık gösterdiği sonucuna ulaşılmıştır. Örgütsel sinizm açısından değerlendirildiğinde öğretmenlerin mesleki kıdemleri örgütsel sinizmin bilişsel sinizm ve davranışsal sinizm boyutlarında anlamlı bir etkiye sahip olduğu sonucuna ulaşılmıştır. Bilişsel sinizm boyutunda 11-15 yıllık mesleki kıdeme sahip olan öğretmenler 1-5 yıllık ve 16-20 yıllık kıdeme sahip öğretmenlere göre bilişsel sinizm davranışını daha fazla gösterdikleri ifade edilebilir. Davranışsal sinizm boyutunda ise 
1-5 yıllık, 6-10 yıllık ve 11-15 yıllık mesleki kıdeme sahip öğretmenlerin 16-20 yıllık mesleki kıdeme sahip öğretmenlere göre kurumlarında daha fazla davranışsal sinizm algısına sahip olduğu söylenebilir. Balay, Kaya ve Cülha (2013) tarafından yapılan araştırma öğretmenlerin örgütsel sinizm algılarının kıdem değişkenine göre farklılaştığı 6-10 yıllık mesleki kıdeme sahip öğretmenlerin örgütsel sinizm algılarının daha yüksek olduğu sonucuna ulaşılmıştır. Şamdan (2019) tarafından yapılan araştırmada öğretmenlerin örgütsel sinizm algılarının kıdem değişkenine göre anlamlı farklılık gösterdiği 21 ve üzeri yıllık kıdeme sahip öğretmenlerin diğer öğretmenlere göre örgütsel sinizm algılarının daha düşük olduğu sonucuna ulaşılmıştır. Helvacı ve Çetin (2012) tarafından yapılan bir başka araştırma da ise öğretmenlerin örgütsel sinizm algılarının kıdem değişkenine göre farklılaşmadığı sonucuna ulaşılmıştır. Kalağan ve Güzeller (2010) tarafından yapılan araştırmada öğretmenlerin örgütsel sinizm algıları cinsiyet ve medeni durum değişkenine göre anlamlı bir farklılık göstermediği, kıdem değişkeni açısından ise anlamlı bir farklılık gösterdiği mesleki kıdemi az olan öğretmenlerin örgütsel sinizm algılarının daha yüksek olduğu sonucuna ulaşılmıştır. Şamdan (2019) tarafından yapılan araştırmada öğretmenlerin örgütsel sinizm algılarının medeni durum ve branş değişkenine göre anlamlı bir farklılık göstermediği, cinsiyete göre anlamlı bir farklılık gösterdiği kadın ögrretmenlerin erkek öğretmenlere daha örgütsel sinizm algılarının daha yüksek olduğu sonucuna ulaşılmıştır. Görev yapılan okul türünün örgütsel sinizm üzerindeki etkisine bakıldığında ortaokul öğretmenlerinin kurumlarında bilişsel sinizm, duyuşsal sinizm ve genel örgütsel sinizm davranışlarını ilkokul öğretmenlerine göre daha fazla sergilediklerini söyleyebiliriz. Şamdan (2019) tarafından yapılan araştırmada öğretmenlerin örgütsel sinizm algılarının okul türüne göre farklılık gösterdiği ortaokul öğretmenlerinin örgütsel sinizm algılarının ilkokul öğretmenlerine göre daha yüksek düzeyde olduğu sonucuna ulaşılmıştır.

\section{Üçüncü Alt Probleme İlişkin Sonuçlar}

Öğretmenlerin örgütsel adalet algıları örgütsel sinizm algıları arasında negatif yönlü anlamlı bir ilişki olduğu ortaya çıkmıştır. Ahmad ve Musa (2016), Akbulut (2020), Alkış ve Kılınç (2016), Bernerth, Armenakis, Feild ve Walker (2007), Biswas ve Kapil (2017), Bölükbaşığlu (2013), Çetin, Özgan ve Bozbayındır (2013), Dar, Khan ve Rauf (2020),Efeoğlu ve İplik (2011), Güzel ve Ayazlar (2014), Korkut (2019), Köybaşı, Uğurlu ve Öncel (2017), Mavibaş (2017), Özge Özgen ve Turunç (2017), Shaharruddin, Ahmad ve Musa. (2016), Şamdan (2019), Singh ve Dixit (2019), Şamdan ve Atanur-Başkan (2019), Uludă̆ (2018), tarafından yapılan araştırma sonuçları bu sonucu desteklemektedir. Örgütsel sinizmin alt boyutları açısından incelendiğinde ise öğretmenlerin örgütsel adalet algıları ile örgütsel sinizmin bilişsel sinizm, duyuşsal sinizm ve davranışsal sinizm alt boyutları arasında negatif yönlü anlamlı bir ilişki olduğu sonucuna ulaşılmıştır. Bu sonuçlardan hareketle öğretmenlerin okullarında örgütsel adalet algılarının zayıflamasının öğretmenlerin okullarına karşı sinik davranışları arttıracağını ifade edebiliriz. Öğretmenler okullarında adaletli bir yönetim anlayışının olmamasında dolayı okullarına karşı olumsuz tutumlar geliştirebilir ve buda öğretmenlerin örgütsel sinizm davranışlarını arttırabilir. Bozbayındır ve Kayabaşı (2014) yaptıkları araştırmada öğretmenlerin örgütsel sinizm davranışlarını arttıran yöneticiden kaynaklı nedenleri, "değer vermeme, adaletsiz 
olma, öğretmenlerin ödüllendirilmemesi, yönetimin yanlış üslubu, aşırı kuralcılık ve yönetimle yaşanan çatışmalar" olarak ifade ettiklerini belirlemiştir. Bu sonuçlar doğrultusunda yönetimde adalet kavramının örgütsel sinizm davranışını etkileyen önemli bir kavram olduğu söylenebilir.

\section{Dördüncü Alt Probleme İlişkin Sonuçlar}

Araştırma sonucuna göre öğretmenlerin örgütsel adalet algıları örgütsel sinizm algılarının bütün alt boyutları ve genel sinizm algıları üzerinde anlamlı bir yordayıcısıdır. Akatay, Yücekaya ve Kısat (2016), Bernerth, Armenakis, Feild ve Walker (2007), Çalışkan (2014), Dar, Khan ve Rauf (2020), Güzel ve Güripek (2020), Kanvur ve Canberk (2018), Kılıç ve Toker (2020), Özge-Özgen ve Turunç (2017), Singh ve Dixit (2019), Şamdan (2019), Şirin, Aydın, Öz ve Şirin (2019), Turgut ve Agun (2016), Yazıcıoğlu ve Özcan- Gençer (2017), Yılmaz ve Polatcı (2018), tarafından yapılan araştırmada da örgütsel adaletin örgütsel sinizm üzerinde anlamlı bir yordayıc1 olduğu sonucuna ulaşılmıştır. Akbulut (2020) tarafından yapılan araştırmada örgütsel adaletin alt boyutları olan dağıtımsal adalet ve etkileşimsel adalet boyutlarının örgütsel sinizm üzerinde anlamlı bir yordayıcı olduğu işlemsel adalet boyutunun ise anlamlı bir yordayıcı olmadığı sonucuna ulaşılmıştır.

Araştırma sonuçları doğrultusunda, öğretmenlerin örgütsel adalete yönelik olumlu algıları arttıkça, okula yönelik olarak sinik tutum sergileme eğilimlerinin azaldığ1 söylenebilir. Öğretmenler tarafından örgütlerine yönelik olarak sergilenen olumsuz duygu, düşünce ve davranışların öğretmenlerin örgütsel adalet algısının azalmasının ve örgütsel sinizmin davranışlarının artmasının sebebi olarak görülebilir.

Örgütsel verimliliğin sağlanmasında çalışanların örgütsel amaçlar doğrultusunda çaba ortaya koyması beklenmektedir. Günümüz çağdaş yönetim anlayışlarında örgütsel amaçların gerçekleşebilmesi için örgüt yönetimlerinin çalışanların beklenti ve ihtiyaçlarını dikkate almaları gerektiği vurgulanmaktadır. Örgütte beklentilerini karşılayamayan çalışanların örgüte karşı olumsuz duygu, düşünce ve davranış sergileyebileceklerini söyleyebiliriz. Örgüt yönetimleri çalışanlarının olumsuz davranışlarını tetikleyen durumları ortadan kaldırıcı düzenlemeleri yapmaları gerekir.

Genel bir değerlendirme yapılacak olursa bu araştırmadan elde edilen sonuçlar genel olarak literatürde yapılan çalışmaların bulgularını destekler niteliktedir. Ancak bazı araştırma sonuçları ile tezatlık oluşturmaktadır.

\section{Öneriler}

Araştırma sonuçlarına dayalı olarak aşağıdaki öneriler geliştirilebilir.

Araştırmacılar için öneriler. Bu araştırma eğitim öğretmenler üzerinde yürütülmüştür. Araştırma farklı meslek grupları üzerinde tekrarlanarak meslekler arasında karşılaştırmalar yapılabilir. Araştırmanın evren ve örneklemi farklılaştırılarak araştırma yeniden yapılabilir. Araştırma nicel yöntemde yapılmıştır. Nitel yöntemde bu araştırma yinelenebilir.

Eğitim yöneticileri için öneriler. Araştırma sonuçlarına göre öğretmenlerin okullardaki adaletli uygulamaları gördükçe okula karşı olumsuz tutumlarında azalma olduğu söylenebilir. Bu doğrultuda okul yöneticilerinin okullarında ödüllendirme, görev dağılımı, insani ilişkiler, yönetmeliklerin uygulanması, disiplin işlemleri gibi 
sonuçları öğretmen davranışlarını etkileyecek iş ve işlemlerde adaletli davranmaları gerekir. Araştırma sonuçlarına göre branş öğretmenlerinin ve ortaokulda görev yapan öğretmenlerin okullarına yönelik olarak örgütsel sinizm davranışlarının yüksek olduğu görülmektedir. Bu durumun nedeni üzerine okul yöneticileri odaklanabilir ve sinik davranışların azaltılması yönünde çözüm yolları aranabilir. Bununla birlikte yöneticilere örgütsel adaleti sağlamada ve öğretmenlerin olumsuz davranışlarını azaltmada milli eğitim müdürlüğü ve milli bakanlığı tarafından destekler sunulabilir.

\section{Kaynakça}

Akatay, A., Yücekaya, P. ve Kisat, N. Ç. (2016). Yöneticilerin etik liderlik davranışlarının, örgütsel adalet ve sinizm üzerine etkileri: Çanakkale İl Emniyet Müdürlüğü'nde bir araştırma. Yönetim Bilimleri Dergisi, 14(28), 483-509.

Akbulut, A. (2020). Öğretmenlerin örgütsel adalet ve örgütsel destek algılarının örgütsel sinizm tutumuna yönelik etkisinin incelenmesi (Yüksek Lisans Tezi). Sebahattin Zaim Üniversitesi, Lisansüstü Eğitim Enstitüsü. İstanbul.

Akdemir, B., Kırmızıgül, B., ve Zengin, Y. (2016). Örgütsel sinizm ile iş performansı arasındaki ilişki ve bir araştırma. Kahramanmaraş Sütçü İmam Üniversitesi İktisadi ve İdari Bilimler Fakültesi Dergisi, 6(2), 115-130.

Akdeniz, A. ve Ottekin Demirbolat. (2019). Ortaokullarda öğretmenlerin örgütsel adalet algıları ile işle bütünleşme algıları arasındaki ilişki. Türk Eğitim Bilimleri Dergisi, 17(2). 418-442

Akyavuz, E. K. (2017). Öğretmenlerin örgütsel adalet ve örgütsel güven algıları arasındaki ilişkinin incelenmesi. Uludă̆ Üniversitesi Eğitim Fakültesi Dergisi, 30(2), 805-831. https://doi.org/10.19171/uefad.369242

Alanoğlu, M. ve Demirtaş, Z. (2019). Öğretmenlerin örgütsel adalet algılarının örgütsel vatandaşlık davranışı üzerindeki etkisi. Marmara Üniversitesi Atatürk Eğitim Fakültesi Eğitim Bilimleri Dergisi, 49(49), $1-16$. https:// doi.org/10.15285/maruaebd.525250

Alkış, H. and Kılınç, S. (2016). The effect of organizational justice on the manners of organizational citizenship and organizational cynicism: A case study on Malatya, Turkey. International Journal of Economics, Commerce and Management, 4(3), 486-508.

Altınkurt, Y., Yılmaz, K., Erol, E., ve Salalı, E. T. (2014). Okul müdürlerinin kullandığ1 güç kaynakları ile öğretmenlerin örgütsel sinizm algıları arasındaki ilişki. Journal of Teacher Education and Educators, 3(1), 25-52.

Andersson, L. M. (1996). Employee cynicism: An examination using a contract violation framework. Human Relationsl. 49, pp. 1395.

Andersson, L. M. and Bateman, T. S. (1997). Cynicism in the workplace: Some causes and effects. Journal of Organizational Behavior,18, 449-460.

Aydın, K. (2015). İlkokul ve ortaokul öğretmenlerinin örgütsel adalet algıları ile işe yabancılaşma algılan arasındaki ilişki: Uşak ili örneği (Yayımlanmamış Yüksek Lisans Tezi). Uşak Üniversitesi, Sosyal Bilimler Enstitüsü, Uşak.

Aydın, Y. T. (2017). Illkokul ve ortaokul öğretmenlerinin örgütsel sinizm ile örgütsel vatandaşlık davranışı ilişkisi: Ankara Altındă̆ ilçesi örneği (Yüksek Lisans Tezi). Balıkesir Üniversitesi, Sosyal Bilimler Enstitüsü, Balıkesir. 
Babaoğlan, E. ve Ertürk, E. (2013). Öğretmenlerin örgütsel adalet alg1sı ile örgütsel adanmışlıkları arasındaki ilişki. Hacettepe Üniversitesi Eğitim Fakültesi Dergisi, 28(28-2), 87-101.

Balay, R., Kaya, A., ve Cülha, A. (2013). Örgüt kültürü ve örgütsel sinizm ilişkisi. Cumhuriyet Üniversitesi İktisadi ve İdari Bilimler Dergisi, 14(2), 123-144.

Baş, G. ve Şentürk, C. (2011). İlköğretim okulu öğretmenlerinin örgütsel adalet, örgütsel vatandaşlık ve örgütsel güven alg1ları. Kuram ve Uygulamada Eğitim Yönetimi Dergisi, 17(1), 29-62.

Batman, N. (2015). Okul öncesi öğretmenlerinin örgütsel adalet algılarının iş tatmin düzeylerine etkisi (Yüksek Lisans Tezi). Gazi Üniversitesi Eğitim Bilimleri Enstitüsü, Ankara.

Bernerth, J. B., Armenakis, A. A., Feild, H. S. and Walker, J. (2007). Justice, cynicism, and commitment: a study of important organizational change variables. Journal of Applied Behavioral Science, 43(3), 303-326.

Biswas, S. and Kapil, K. (2017). Linking perceived organizational support and organizational justice to employees' in-role performance and organizational cynicism through organizational trust. Journal of Management Development, 36(5). 696-711

Blakely, L.G. Andrews, C.M. and Moorman, H.R. (2005). The moderatıng effects of equity sensitivity on the relationship between organizational justice and organizational citizenship behaviors. Journal of Business and Psychology, 20(2). 259-273

Bozbayındır, F. ve Kayabaşı, E. (2013). The reasons and effects of organizational cynicism in secondary schools. Gaziantep Üniversitesi Sosyal Bilimler Dergisi, 13(1), 211-227.

Bölükbaşığlu, K. (2013). Öğretmenlerin örgütsel adalet algıları ile örgütsel sinizm tutumları arasındaki ilişki (Yüksek Lisans Tezi). Pamukkale Üniversitesi, Eğitim Bilimleri Enstitüsü. Denizli

Bursalığlu, Z. (2002). Okul Yönetiminde yeni yapı ve davranış. Ankara: Pegem Akademi Yayıncilik.

Cropanzano, R., Bowen, D. E., and Gilliland, S. W. (2007). The management of organizational justice. Academy of management perspectives, 21(4), 34-48.

Çalışkan, S. (2014). Pozitif örgütsel davranış değişkenleri ile yeni araştırma modelleri geliştirme arayışları: Pozitif örgütsel davranış değişkenlerinin işe adanmışlık, tükenmişlik ve sinizm üzerine etkileri ve bu etkileşimde örgütsel adalet algısının aracılık rolü üzerine. Dokuz Eylül Üniversitesi Sosyal Bilimler Enstitüsü Dergisi, 16(3), 363-382.

Çelik, O. T. ve Gürsel, M. (2017). İlköğretim okulu öğretmenlerinin örgütsel adalet alg1ları ve iş doyumları arasındaki ilişki. İnönü Üniversitesi Eğitim Bilimleri Enstitüsü Dergisi, 4(7), 48 - 56. https:/ / doi.org/10.29129/inujgse.347677

Çetin, B., Özgan, H. ve Bozbayındır, F. (2013). İlköğretim öğretmenlerinin örgütsel adalet ile sinizm algıları arasındaki ilişkinin incelenmesi. Akademik Bakış Dergisi $37,1-20$.

Çiçek-Sağlam, A. ve Emir, A. (2018). Öğretmenlerin örgütsel adalet algıları ile motivasyon düzeyleri arasındaki ilişki. Researcher: Social Science Studies, 6(1), 40 $-56$. 
Dar, N., Khan, S. and Rauf, A. (2020). Deviant behavior and organizational justice: mediator test for organizational cynicism - The Case of Pakistan. Asian Journal of Economics and Finance 2(4), 333-347.

Davis, W. D. and Gardner, W. L. (2004). Perceptions of politics and organizational cynicism: An attributional and leader-member exchange perspective. The leadership quarterly, 15(4), 439-465.

Dean, J. W., Brandes, P. and Dharwadkar, R. (1998). Organizational cynicism. Academy of Management Review, 23, 341-352

Demirda ̆̆, S. (2017). Ücretli öğretmen algılarına göre ilkokul yöneticilerinin örgütsel adalet, örgütsel güven ve yıldırma davranışları arasındaki ilişki. Abant İzet Baysal Üniversitesi Eğitim Fakültesi Dergisi, 17 (1), 132-153. https:// doi.org/10.17240/aibuefd.2017.17.28551-304626

Demirtaş, Z., Özdemir, T. Y. ve Küçük, Ö. (2016). Okulların bürokratik yapısı, örgütsel sessizlik ve örgütsel sinizm arasındaki ilişki. Kuram ve Uygulamada Ĕ̆itim Yönetimi Dergisi, 22(2), 193-216. doi: 10.14527/kuey.2016.008

Efeoğlu, İ. E. ve İplik, E. (2011). Alg1lanan örgütsel adaletin örgütsel sinizm üzerindeki etkilerini belirlemeye yönelik ilaç sektöründe bir uygulama. Çukurova Üniversitesi Sosyal Bilimler Enstitüsü Dergisi, 20(3), 343-360.

Ergen, H. ve İnce, Ş. (2017). İlköğretim kurumlarında çalışan öğretmenlerin örgütsel sinizm düzeyleri: Mersin örneği. Hacettepe Eğitim Araştırmaları Dergisi, 3(1). 3757

Grama, B., and Todericiu, R. (2016). Change, resistance to change and organizational cynicism. Studies in Business and Economics, 11(3), 47-54.

Güçlü, N., Kalkan, F. ve Dağlı, E. (2017). Mesleki ve teknik ortaöğretim okulu öğretmenlerin algılarına göre okul müdürlerinin liderlik stilleri ile örgütsel sinizm arasındaki ilişki. Gazi Üniversitesi Gazi Ĕ̆itim Fakültesi Dergisi, 37(1). 177192

Güneş, A. ve Küçüksüleymanoğlu, R. (2020). Öğretmenlerin örgütsel adalet algıları ile örgütsel vatandaşlık davranışları arasındaki ilişki. Yaşadıkça Ĕ̆itim, 34(2), 313330.

Güngör, S. K. ve Potuk, A. (2018). Öğretmenlerin mobbing, örgütsel adalet ve örgütsel sessizlik algıları ve aralarındaki ilişki. Hacettepe Üniversitesi Ĕ̆itim Fakültesi Dergisi, 33(3), 723-742.

Güzel, B. ve Ayazlar, G. (2014). Örgütsel adaletin örgütsel sinizm ve işten ayrılma niyetine etkisi: otel işletmeleri araştırması. Karamanoğlu Mehmetbey Üniversitesi Sosyal ve Ekonomik Araştırmalar Dergisi, (1), 133-142.

Güzel, B. ve Güripek, E. (2020). Örgütsel adalet, sapkın davranış, örgütsel sinizm ve işten ayrılma niyeti ilişkisi: karş1l1lık normu yaklaşımı. Journal of Tourısm And Gastronomy Studies, 8(2). 870-895. DOI: 10.21325/jotags.2020.585

Hazzi, O. A. (2012). Organizational justice: The sound investment in organizations. European Journal of Economics, Finance and Administrative Sciences, 52, 163-169.

Helvacı, M. A. ve Çetin, A. (2012). İlköğretim okullarında görev yapan öğretmenlerin örgütsel sinizm düzeylerinin belirlenmesi (Uşak ili örneği). Turkish Studies, 7(3 b), $1475-1497$. 
Hoy, W. K. and Tarter, C. J. (2004). Organizational justice in schools: No justice without trust. International Journal of Educational Management. 18(4). 250-259

İnceoğlu, M. (2010). Tutum Alg̨ İletişim. İstanbul: Beykent Üniversitesi Yayınevi.

İşbaşı, J.Ö. (2000). Çalışanların yöneticilerine duydukları güvenin ve örgütsel adalete ilişkin algilamalarmın örgütsel vatandaşlık davranışının oluşumundaki rolü: Bir turizm örgütünde uygulama (Yüksek Lisans Tezi). Akdeniz Üniversitesi, Sosyal Bilimler Enstitüsü, Antalya.

İşleyici, K. (2015). Örgütsel adalet ve örgütsel sessizlik arasındaki ilişkinin incelenmesi Zonguldak ili örneği ( Yüksek Lisans Tezi). Abant İzzet Baysal Üniversitesi, Eğitim Bilimleri Enstitüsü, Bolu.

Kaba, A. (2018). Bireylerin nepotizm ve örgütsel adalet algılarnın bireysel performanslarnna etkisi: Türkiye'de özel okul zinciri çalışanları üzerinde bir araştırma (Yüksek Lisans Tezi). Bahçeşehir Üniversitesi Sosyal Bilimler Enstitüsü, İstanbul.

Kahveci, G., Kandemir, İ. K., ve Bayram, S. (2019). Öğretmenlerin örgütsel ikiyüzlülük ile örgütsel adalet algıları arasındaki ilişkinin incelenmesi. Elementary Education Online, 18(2). 788-807. https://www.ilkogretim-online.org/. DOI: https:// doi.org/10.17051/ilkonline.2019.562061

Kalağan, G. ve Güzeller, C. O. (2010). Öğretmenlerin örgütsel sinizm düzeylerinin incelenmesi. Pamukkale Üniversitesi Eğitim Fakültesi Dergisi, 27(27), 83-97.

Kalman, M. ve Gedikoğlu, T. (2014). Okul yöneticilerinin hesap verebilirliği ile örgütsel adalet arasındaki ilişkinin incelenmesi. Hacettepe Üniversitesi Ĕgitim Fakültesi Dergisi, 29(29-2), 115-128.

Karasar, N. (2007). Bilimsel araştırma yöntemleri (17. Baskı). Ankara: Nobel Yayınevi.

Kaya, T. (2014). Okul yönetiminde etik liderlik ve örgütsel adalet ilişkisi (Yüksek Lisans Tezi). Mevlana Üniversitesi Sosyal Bilimler Enstitüsü, Konya.

Kılıç, S. ve Toker, K.(2020). Örgütsel adalet ile örgütsel sinizm arasındaki ilişkinin incelenmesi. Journal of Yaşar University, 15(58), 288-303.

Korkut, A. (2019). Öğretmenlerin örgütsel mutluluk, örgütsel sinizm ve örgütsel adalet algılarının analizi (Doktora Tezi). İnönü Üniversitesi Eğitim Bilimleri Enstitüsü. Malatya

Korkut, A., Çelik, O. T. ve Atik, S. (2015). Eğitim Yönetimi ve Denetimi alanında yapılmış olan örgütsel adalet konulu makalelerin karşılaştırmalı analizine dair bir araştırma. EYFOR VI Uluslararası Eğitim Yönetimi Forumu (5-7 Kasım 2015, Girne, KKTC).

Köybaşı, F., Uğurlu, C. T. ve Öncel, A. (2017). Öğretmenlerin örgütsel adalet algıları ile örgütsel sinizm düzeyleri arasındaki ilişkinin incelenmesi. Inönü Üniversitesi Eğitim Fakültesi Dergisi, 18(1). 1-14. https:/ / doi.org/10.17679/inuefd.285527

Kurtulmus, M. ve Karabiyik, H. (2016). Algılanan örgütsel adaletin öğretmenlerin işe yabanc1laşma düzeylerine etkisi. Bartın Üniversitesi Eğitim Fakültesi Dergisi, 5(2), 459-477. https:/ / doi.org/10.14686/buefad.v5i2.5000175962

Kutanis R. Ö. ve Dikili, A. (2010). Değişim boyutunda örgütlerde sinizm. D. E. Özler (Ed.), Örgütsel Davranışta Güncel Konular içinde (269-285), Bursa: Ekin Basım Yayın Dağıtım

Naus, F., Van Iterson, A., ve Roe, R. (2007). Organizational cynicism: Extending the exit, voice, loyalty, and neglect model of employees' responses to adverse conditions in the workplace. Human relations, 60(5), 683-718. 
Mavibaş, M.(2017). Spor bilimleri fakültelerinde görev yapan akademik personelin örgütsel adalet algılar ile örgütsel sinizm tutumlarnın incelenmesi (Yüksek Lisans Tezi). Atatürk Üniversitesi Sosyal Bilimler Enstitüsü. Erzurum.

Özdevecioğlu, M. (2003). Algilanan örgütsel adaletin bireylerarası saldırgan davranışlar üzerindeki etkilerinin belirlenmesine yönelik bir araştırma. Erciyes Üniversitesi İktisadi İdari Bilimler Fakültesi Dergisi, 21, 77-96.

Özer, G. ve Günlük M. (2010). Örgütsel adaletin muhasebecilerin iş memnuniyeti ve işten ayrılma eğilimine etkisi. Gaziantep Üniversitesi Sosyal Bilimler Dergisi, 9(2), $459-485$.

Özgen, F. Ö. ve Turunç, Ö. (2017). Örgütsel adalet-sinizm ilişkisinde kişi örgüt uyumunun rolü: eğitim sektöründe bir araştırma. Uluslararası İktisadi ve İdari Bilimler Dergisi, 3(2), 80-96.

Polat, S. (2007). Ortaöğretim öğretmenlerinin örgütsel adalet algıları, örgütsel güven düzeyleri ile örgütsel vatandaşlık davranışları arasındaki ilişki (Doktora Tezi). Kocaeli Üniversitesi Sosyal Bilimler Enstitüsü. Kocaeli

Polat, S. ve Celep, C. (2008). Ortaöğretim öğretmenlerinin örgütsel adalet, örgütsel güven, örgütsel vatandaşlık davranışlarına ilişkin algıları. Kuram ve Uygulamada Ĕ̆itim Yönetimi Dergisi, 14(2), 307-331.

Polatc1, S. ve Yılmaz, H.(2018). Örgütsel adalet algısı ve personel güçlendirmenin iş performansina etkisi: örgütsel sinizmin rolü. International Journal of Social Science, 1(2), 286-308.

Shaharruddin, S., Ahmad, F. and Musa, M. M. (2016). Cynicism in organizations: does organizational justice matter? International Journal of Research in Business Studies and Management, 3(2), 49-60.

Singh, D. and Dixit, V. (2019). The effect of job embeddedness and organizational justice on organizational cynicism: A Study of ITIndustry in Delhi-NCR. Journal of the Gujarat Research Society, 21(11), 532-543.

Şahin, R. ve Kavas, E. (2016). Örgütsel adalet ile örgütsel bağlılık arasındaki ilişkinin belirlenmesinde öğretmenlere yönelik bir araştırma: Bayat örneği. Süleyman Demirel Üniversitesi Vizyoner Dergisi, 7(14), 119 - 140. https://doi.org/10.21076/vizyoner.245975

Şamdan, T. (2019). İlkokul ve ortaokul öğretmenlerinin algilarına göre örgütsel adalet ve örgütsel sinizm arasındaki ilişkinin incelenmesi (Doktora Tezi). İstanbul Okan Üniversitesi Sosyal Bilimler Enstitüsü. İstanbul

Şamdan, T. ve Baskan, G. A. (2019). Öğretmenlerin alg1larına göre örgütsel adalet ve örgütsel sinizm arasındaki ilişkinin incelenmesi. Pamukkale Üniversitesi Ĕ̆itim Fakültesi Dergisi, 47, 17-40. doi: 10.9779/pauefd.479173

Şirin, Y. E., Aydın, Ö., Öz, G., ve Şirin, T. (2019). Beden eğitimi ve spor yüksekokulu öğretim elemanlarının örgütsel adalet ve örgütsel sinizm algılamalarının incelenmesi. Turkish Studies, 14(1). 291-306. DOI:10.7827/TurkishStudies.14785

Turgut, T. ve Agun, H. (2016). Örgütsel adalet ile örgütsel sinizm arasındaki ilişkide psikolojik sermaye ve çalışan sesliliğinin ara değişken rolü. İş'te Davranış Dergisi, 1(1), 15-26. https:/ / doi.org/10.25203/idd.276269

Uludağ, O., Aktaş, İ. ve Özgit, H. Ö. (2019). Eğitim çalışanlarının örgütsel adalet algılarının ve örgüt kültürünün bilgi paylaşımı üzerindeki etkileri: Örgüt 
kültürünün aracı rolü. Hacettepe Üniversitesi Eğitim Fakültesi Dergisi, 34(1), 160181. doi: 10.16986/HUJE.2018037423

Uludağ, T.(2018). Sinıföğretmenlerinin örgütsel adalet algılarn ile örgütsel sinizm tutumları arasındaki ilişki (Yüksek lisans tezi). İstanbul Sebahattin Zaim Üniversitesi Sosyal Bilimler Enstitüsü. İstanbul

Uzun, T. (2018). Okullarda alg1lanan örgütsel adalet, yönetici desteği ve örgütsel özdeşleşme arasındaki ilişki. Trakya Üniversitesi Eğitim Fakültesi Dergisi, 8(4), 776-789. Doi: 10.24315/trkefd.366093

Uzun, T. ve Ayık, A. (2016). Okul müdürlerinin iletişim becerileri ile öğretmenlerin genel ve örgütsel sinizm tutumları arasındaki ilişkilerin incelenmesi. Mersin Üniversitesi Eğitim Fakültesi Dergisi, 12(2), 672-688. https:// doi.org/10.17860/efd.87017

Ünlü, Y., Hamedoğlu, M. A. ve Yaman, E. (2015). Öğretmenlerin örgütsel adalet algıları ve örgütsel sessizlik düzeyleri arasındaki ilişki. Sakarya University Journal of Education, 5(2), 140-157.

Wilkerson, J. M., Evans, W. R. and Davis, W. D. (2008). A test of coworkers' influence on organizational cynicism, badmouthing, and organizational citizenship behavior. Journal of Applied Social Psychology, 38(9), 2273-2292.

Williams, S., Pitre, R. and Zainuba, M. (2002). Justice and organizational citizenship behavior intentions: Fair rewards versus fair treatment, The Journal of Social Psychology, 142(1), 33-44.

Yazıcıoğlu, İ., ve Gençer, E. Ö. (2017). Örgütsel adalet algısının sinizm üzerine etkisi: Devlet Üniversiteleri Meslek Yüksekokullarında bir araştırma. İşletme Araştırmaları Dergisi 9(4). DOI:10.20491/isarder.2017.323

Yıldırım, İ., Akan, D., ve Yalçın, S. (2019). Okullarda örgütsel sinizmin yordayıcısı olarak karar verme sürecine katılım. Bartın Üniversitesi Ë̆itim Fakültesi Dergisi, 8(2), 487-506. DOI:10.14686/buefad.444354

Yıldız, K. (2013). Örgütsel bağl1lık ile örgütsel sinizm ve örgütsel muhalefet arasındaki ilişki. Turkish $\quad$ Studies, 8(6). 853-879. http:/ / dx.doi.org/10.7827/TurkishStudies.4544

Yılmaz, K. (2010). Devlet ortaöğretim okullarında görev yapan öğretmenlerin örgütsel adalet algiları. Kuram ve Uygulamada Eğitim Bilimleri, 10(1). 579-616

Yorulmaz, A. ve Çelik, S. (2016). İlkokul öğretmenlerinin örgütsel bağl1lık, örgütsel sinizm ve örgütsel vatandaşlık davranışları arasındaki ilişki. Kalem Eğitim ve Insan Bilimleri Dergisi, 6(1), 161-193. DOI:10.23863/kalem.2017.60

Yücekaya, P. ve Sönmez-Polat, D. (2020). Örgüt kültürü, örgütsel adalet ve iş tatmini ilişkisi üzerine bir araştırma. İşletme Araştırmaları Dergisi, 12(2), 1267-1284. DOI:10.20491/isarder.2020.910

\section{Summary}

\section{Introduction}

Organisations arise from human needs. Organisations' achieving their goals is significant in terms of continuing their existences. Achieving the organisational goals depends on the efforts of the employees in line with the organisational goals. In order to achieve the organisational goals, employees ensure to actualise both the goals of the 
organisation and their own needs by putting forth an effort. In this sense, a network of relationship may be mentioned between the organisation and the employee to meet mutual needs and expectations.

In today's organisational life, the factor of complexity and competition forces organisations to evolve in order to compete and make a profit (Grama and Todericiu, 2016). With globalisation and the increase in competition, the reality that the basic element of achieving organisational success is human resources provoke the organisations to increase their interest in human resources (Hazzi, 2012).

Schools are places, in which there are complicated and comprehensive relationships and teachers, administrators, student and parent stakeholders interact. One of the most significant factors that determine the direction of the interaction, is the leadership of the school administrator and the management approach demonstrated while managing the school. This sort of behaviour and approach, his/her impression and/or way of perception encourage teachers. Unfair actions and 'nepotism' behaviours of school administrators may be factors that direct teachers inefficiency in many ways. This sort of practices can lead teachers to cynical attitudes, low perception of justice, opposition behaviour and unhappiness (Korkut, Çelik and Atik, 2015).

\section{Method}

The research was designed with the relational screening model, among the quantitative research methods. The relationship between the organisational justice perceptions and organisational cynicism perceptions of teachers was investigated in this research. The existence and/or level of difference together between two or more variables was tried to be determined with the relational screening model (Karasar, 2007).

The study group consisted of 240 teachers, selected with the random sampling method, working in the city centre of Erzincan province in the 2018-2019 educational year. There are 48 primary school (597 teachers), 38 secondary schools (855 teachers) and 33 high schools (991 teachers) in the city centre of Erzincan province.

\section{Results}

According to the research results, it is realised that the teachers have a high level of organisational cynicism; however low cognitive cynicism, affective cynicism, behavioural cynicism and organisational cynicism perceptions. In addition, the results suggest that while the organisational justice and organisational cynicism perceptions of teachers demonstrate no significant difference according to the gender and marital status variables, their organisational justice, cognitive cynicism, affective cynicism, behavioural cynicism and organisational cynicism perceptions demonstrate significant difference according to their content knowledge. Considering another result, while there is no significant difference between the organisational justice, affective cynicism and general organisational cynicism perceptions of the teacher according to the variable of the year of experience, in the cognitive and behavioural dimensions of their organisational cynicism perceptions, a significant difference was encountered according to the variable of the year of experience. According to another result, it can be claimed that a negative high level of significant difference $(r=-, 763)$ has been found between organisational justice and organisational cynicism. As the relationship between the sub-dimensions of organisational justice and organisational 
cynicism is taken into account, it can be referred that there is a negative high level of a significant relationship between organisational justice and cognitive cynicism $(\mathrm{r}=-$ ,712), a negative moderate level of a significant relationship between organisational justice and affective cynicism $(\mathrm{r}=-, 653)$, a negative significant relationship between organisational justice and behavioural cynicism $(\mathrm{r}=-, 574)$.

Within the lights of these results, it can be claimed that as the organisational justice perceptions of teachers increase, their organisational cynicism behaviours decrease. In other words, it can be referred that fair practices in schools decrease teachers' negative thoughts and behaviours towards their schools. According to the results of the research, it is realised that the organisational cynicism perceptions of teachers are the significant predictors of their cognitive cynicism, affective cynicism, behavioural cynicism and general organisational cynicism perceptions and approximately $50 \%$ of the cognitive cynicism, $43 \%$ of the affective cynicism, $33 \%$ of the behavioural cynicism and $58 \%$ of the general organisational cynicism originate from the organisational justice perceptions of teachers.

\section{Discussion}

The organisational justice perceptions of teachers was found to be high. Considering these results, it can be expressed that the teachers have positive justice feelings in their schools and found their principals fair during the school management process. In the study conducted by Alanoğlu and Demirtaş (2019), Babaoğlan and Ertürk (2013), Demirdağ (2017), Kahveci, Karagül Kandemir and Bayram (2019), Kıranl1-Güngör and Potuk (2018), Korkut (2019), Kurtulmuş and Karabıyık (2016), Külekçi and Akyavuz (2017), Şahin and Kavas (2016), Şamdan and Atanur-Başkan (2019), Uludağ, Aktaş and Özdoğaç-Özgit (2019), Uzun (2018) it was found that the organisational justice perceptions of teachers were high.

As a result of the analyses, while there was no significant difference between the organisational justice and organisational cynicism perceptions of the teacher according to gender and marital status, a significant difference was encountered between the organisational justice and general organisational cynicism and all of the sub-dimensions perceptions of teachers according to the variable of content knowledge. In the research by Polat and Celep (2008), it is referred that the organisational justice perceptions of teachers demonstrate a significant difference in favour of male teachers. In the research by Baş and Şentürk (2011), the organisational justice perceptions of teachers did not demonstrate any significant difference according to gender, year of experience variables.

A negative significant relationship was found between the organisational justice perceptions and organisational cynicism perceptions of teachers. The results reached by Akbulut (2020), Alkış and Kılınç (2016), Bernerth, Armenakis, Feild and Walker (2007), Biswas and Kapil (2017), Bölükbaşıŏlu (2013), Çetin, Özgan and Bozbayındır (2013), Dar, Khan and Rauf (2020), Efeoğlu and İplik (2011), Güzel and Ayazlar (2014), Korkut (2019), Köybaşı, Uğurlu and Öncel (2017), Mavibaş (2017), Özge-Özgen and Turunç (2017), Shaharruddin, Ahmad and Musa (2016), Singh and Dixit (2019), Şamdan (2019), Şamdan and Atanur-Başkan (2019), Uludağ (2018), support this result.

\section{Araştırmanın Etik İzinleri}

Yapılan bu çalışmada "Yükseköğretim Kurumları Bilimsel Araştırma ve Yayın Etiği Yönergesi" kapsamında uyulması belirtilen tüm kurallara uyulmuştur. Yönergenin 
ikinci bölümü olan “Bilimsel Araştırma ve Yayın Etiğine Aykırı Eylemler” başlığı altında belirtilen eylemlerden hiçbiri gerçekleştirilmemiştir.

Etik kurul izin bilgileri

Etik değerlendirmeyi yapan kurul ad1 $=$ Erzincan Binali Yıldırım Üniversitesi İnsan Araştırmaları Etik Kurulu

Etik değerlendirme kararının tarihi $=18.12 .2020$

Etik değerlendirme belgesi sayı numarası=11/15

\section{Authors' Biodata/ Yazar Bilgileri}

Associate Professor Sinan Yalcin is a faculty member at the Department of Educational Sciences, Faculty of Education, Erzincan Binali Yıldırım University. His areas of interest include educational administration, classroom management, leadership and teacher qualifications.

Doç. Dr. Sinan YALÇIN, Erzincan Binali Yıldırım Üniversitesi Eğitim Fakültesi Eğitim Bilimleri Bölümünde öğretim üyesidir. İlgi alanları arasında eğitim yönetimi, sınıf yönetimi, liderlik ve öğretmen nitelikleri yer almaktadır 